Article

\title{
The Life Cycle of Corporate Social Responsibility in Agri-Food: Value Creation Models
}

\author{
Concetta Nazzaro *(1), Marcello Stanco $₫$ and Giuseppe Marotta $₫$ \\ Department of Law, Economics, Management and Quantitative Methods, University of Sannio, 82100 Benevento, \\ Italy; mstanco@unisannio.it (M.S.); marotta@unisannio.it (G.M.) \\ * Correspondence: cnazzaro@unisannio.it
}

Received: 9 December 2019; Accepted: 17 January 2020; Published: 11 February 2020

check for updates

\begin{abstract}
This paper contributes to the theoretical debate in agri-food economics focusing on corporate social responsibility. Specifically, it aims to define an interpretative model of the processes of social responsibility and value creation in the food industry. An empirical investigation was conducted using an analysis of case studies-representative of sustainable innovation and social responsibility models-as well as in-depth interviews and focus groups with managers of food industries and the sector's experts. The paper focuses on a topic that has yet to be analysed in agri-food economics literature: corporate social responsibility as a value-creating strategy. Further, it proposes a life cycle model of social responsibility in business processes. The study findings reveal that corporate social responsibility actions may affect the agri-food process and/or the product. Specifically, the investigated case studies reveal that the production sector in which a company operates strongly influences its orientation towards one or more corporate social responsibility dimensions. This study's results contribute to the debate on the topic and provide useful insights for practitioners and policy-makers.
\end{abstract}

Keywords: corporate social responsibility; life cycle; sustainable innovation; food companies; value creation

\section{Introduction}

Changes in citizens' values, lifestyles, and preferences-as well as a new business culture that considers the environmental and social impacts of productive activity [1,2] -have increased interest in the agricultural economics field towards the concept of corporate social responsibility (CSR).

The CSR concept was first introduced in management literature in the 1950s as "the obligations of businessmen to pursue those policies, to make those decisions, and to follow those lines of action that are desirable in relation to the objectives and values of our society" [3]. Subsequently, many works on the topic have been developed, with several definitions of CSR. Currently, CSR still lacks a unique definition $[4,5]$.

From a conceptual perspective, scholars, in their research, have implemented either the definitions provided in management literature [2] or those developed in the community context. In the latter, CSR has been defined [6] as "the voluntary integration of companies' social and ecological concerns in their business operations in strict collaboration with stakeholders" [6]. Moreover, to be socially responsible, companies must both accomplish and surpass their legal duties by investing in human capital, the environment and their relationships with stakeholders.

The European strategy [7] also focuses on the concept of a corporate responsibility towards society. In this context, CSR is a tool through which companies implement legitimate business operations, obtaining their "license to operate" [8,9] and improving their reputation with positive effects on companies' financial performance $[10,11]$. Companies' economic, ecological and social duties are connected in a triple bottom line [12] though which CSR can be assessed using three dimensions: 
economic, environmental and social. Companies are sustainable when they achieve goals involving all three Ps in the bottom line: profit, people and the planet [13]. Therefore, CSR "leads to the search for a virtuous balance between economic development, environmental protection, and social promotion" [14].

Based on these assumptions, several scholars consider CSR as a tool through which companies can implement sustainable development [1,15-20]. Additionally, they consider the difference between sustainable development, which implies a collective long-term responsibility, and CSR; a clear complementarity exists between them, affirming that policies and decisions must be adopted through a broader vision to obtain long-term benefits [20].

The absence of a unanimously accepted definition aimed at clarifying the scope of CSR has not affected its role in the agri-food sector given the aspects that distinguish agri-food companies' activities. More than any other sector, agri-food is characterised by a significant dependence on natural resources and considerably impacts the environment and biodiversity; therefore, this sector's companies are highly exposed to environmental associations and civil society in general [1]. Additionally, agri-food companies face several social problems and ethical issues concerning their supply chain [1], such as the use of genetically modified organisms, the safety of produced foods or animal welfare $[9,21]$. The greater public visibility of the agri-food industry and its perceived external pressures may be the reasons that push these companies, and especially larger ones, to adopt socially responsible behaviours $[8,22,23]$. This may also be why these companies' actual socially responsible actions are sometimes less substantial than their stated commitments [24]. Moreover, the tight bond between agribusiness and the environment has led some scholars to examine the limits to which social responsibility must extend [25], or specifically, whether this responsibility should be limited to company boundaries or should involve the entire food supply chain.

Effective social responsibility must affect the entire supply chain [26,27]. Further, Kissinger [28] also notes that when the CSR extends to the entire food supply chain, it can contribute to decreasing agricultural greenhouse gas emissions. Some authors have also demonstrated that CSR can extend to the entire supply chain, and especially, an agri-food company with proactive, sustainable behaviours can also influence other stakeholders [29,30]. However, Wiese and Toporowski [31] revealed that when social responsibility extends to the entire food supply chain, the risk exists that a company acting undesirably can damage the reputation of some or all of its associated companies.

The literature has primarily investigated CSR from the consumer's perspective, noting that it generates value-added benefits by affecting consumers' perceptions towards companies and products while increasing consumers' loyalty and satisfaction [32-39]. The latter leads to a higher willingness to pay for socially responsible companies' products [40,41]. Further, CSR also increases a company's attractiveness as an employer while enhancing employee satisfaction [42-44].

Moreover, CSR positively influences innovation strategies, as it compels companies to constantly increase their products' quality and implement sustainable processes towards innovation. Therefore, CSR strengthens companies' reputations, with benefits to their image and identity, and in consumers' recognition of the brand and the company's products [11,14,37,45].

Existing literature clearly indicates that CSR can be conceived as a tool through which agri-food companies can increase their competitiveness. Forsman-Hugg et al. [46] were among the first scholars in agri-food literature to connect CSR to companies' competitive advantage, suggesting that it functions to provide "elements to build new types of resources that may serve as a foundation for a competitive advantage" [46]. Indeed, CSR is crucial, not only for products' differentiation in the market, but also for companies' more efficient use of resources [27,47].

More recently, CSR has been interpreted as a strategy of competitive advantage for value creation in agri-food companies [14]. The evolution of competitive dynamics has enabled companies to conceive their business activities in the context of value-creation models aiming to meet citizen-consumers' emerging needs. Further, companies focus on productive models centred on protecting natural and environmental resources as well as on consumer protection, in which CSR is a competitive lever 
used to promote sustainable innovation or decrease production costs and create positive externalities. Subsequently, CSR became a strategic factor to enable companies aiming to become more socially aware to address challenges related to the environment and consumer protections.

These concerns should characterise the organisational culture and guide decision-making and the business process. Consequently, competition should occur based on the promotion of distinctive values generated by social responsibility that can improve companies' reputations.

The CSR debate has generated different interpretations on the topic. The current study considers CSR in an original way as a strategic behavioural function to drive companies' innovation activities towards new value-creation paths (multi-value farm). Specifically, it relates to the competitive business strategies that enable companies to differentiate themselves by internalising society's social, environmental and economic needs. The latter should be reflected in the characterisation of the company's organisational culture and should guide its decision-making and business processes. However, it is difficult to observe the contextual presence of all three CSR dimensions in a company, as different orientation processes can often be observed.

Accordingly, this study, on the one hand, aims to define a theoretical and methodological framework that can interpret the different levels of CSR orientation (a CSR life cycle model) among agri-food companies, while, on the other hand, investigating how this impacts enterprises' implemented value-creation models.

\section{Corporate Social Responsibility and Value Creation Models: A Conceptual Framework}

\subsection{The Sustainable and Multi-Value Agri-Food Company}

At the beginning of the 1980s, a rigorous regulatory framework was shaped to protect natural and environmental resources. As a result, agri-food companies had to implement waste management processes to substantially modify their production cost structures. Companies then had to address both environmental and social issues, such as labour and food safety regulations.

First, the purported civil law model [14] exclusively considered both the costs and negative competitive effects from the environmental and social issues companies faced when adopting an economic perspective.

The peculiarity of the Italian agri-food sector-characterised by the prevalence of small and medium-sized enterprises-has further pronounced the economic perspective towards environmental and social issues. This economic perspective dominated at the end of the 20th century, but has been overcome in the past few years (common law phase) under pressure from the European Union (EU) to favour a new entrepreneurial vision to deeply change companies' strategic management toward environmental, health-related and social issues.

The EU strongly promoted a new CSR-based business culture, as reflected in company policies, to integrate citizens' and consumers' concerns about environmental and social issues. To support this initiative, the EU launched several research and development policies aiming to promote new, healthy and functional products as well as sustainable production systems. This new, common research and development policy has led to substantial changes in companies' approaches to environmental and social issues. The offer of sustainable innovation, as derived from the research and development programs promoted by the new EU policy, has enabled the agri-food sector to address a prominent issue involving the processing of waste materials. Therefore, wastes are no longer considered merely a problem or cost, but as an input for energy production or recyclable materials for packaging. In other words, the issue was transformed into an opportunity to create value through internal economies that positively reflect companies' performance. Simultaneously, food technology research results in recent years have enabled the commercialisation of products that are healthier and clearly convey their social benefits, contributing to citizen-consumers' lives and well-being.

Another CSR aspect to consider is associated with social relationships, both internal and external. Regarding the former, factors that positively influence the connection between employees 
and the company include the tension in continuously training employees and improving human capital, the company's attention to work conditions, the socialisation of company problems, and the consideration of workers as "people" who can express their needs and expectations for themselves and their families. These factors also generate a strong sense of belonging and identity among employees, resulting in internal economies for the company. Workers will then increase their trust in the company and management, which will reduce internal conflicts and increase the motivation to work as well as increasing productivity and business profits. As for the external dimension, agri-food companies' socially responsible behaviour will encourage relationships with suppliers of raw materials and the local community, which will increase their trust of the enterprise. As indicated in the literature, this scenario, on the one hand, reduces transaction costs, while, on the other hand, decreases the costs of access to external services, such as policy-making, as influenced by relationships with local institutions, banks, and the public sector.

On the external side, the company's credibility and reputation improve its exchanges and relationships, which activates external social economies as lower transaction and bureaucratic costs that directly and indirectly influence business profits.

The company's ability to produce social benefits for the local community by promoting ethical values [48] improves its market position by increasing how often modern citizen-consumers evaluate its products. The latter will not only prefer socially responsible companies' products and services, but will also express a higher willingness to pay (WTP) for premium prices for their products.

The agri-food company can apply new food technologies to produce healthy, safe and functional products. The adoption of sustainable technologies can better process wastes and internalise the production of energy as obtained from renewable sources, water and recyclable materials for packaging (internal economies).

(a) It can adopt relationships oriented towards social responsibility to improve productivity and, therefore, profits; externally, it can decrease the costs of transactions and those related to the access to services and policies (external economies).

(b) The orientation towards social responsibility, along with food and other goods and services (market output), generates public goods (not market output), such as environmental or natural resources and health and ethical values, as well as fewer social costs, that determine reputational effects. These induce citizen-consumers to prefer the company's goods and services. Citizen-consumers are also willing to recognise premium prices, compared to the goods and services of non-socially responsible food companies. The results are also positive for companies' economic performance (external social economies).

Figure 1 illustrates that socially responsible agri-food companies can develop several value chains (VCs) and governance structures to produce value both directly (market output) and indirectly (non-market output). The latter generates a specific value portfolio [14,49].

In summary, the orientation towards social responsibility and the implementation of tangible and intangible value chains satisfies citizen-consumers' economic, environmental and social expectations. These determine companies' new social roles and facilitate their exceptional economic performance.

The sustainable agri-food company includes a set of governance structures to create multidimensional value, while socially responsible behaviours include the establishment of competitive strategies to produce distinctive social qualities and build reputational capital.

Accordingly, the environmental and social aspects become the main assets of a competitive strategy, revealing products' distinctive qualities. However, and perhaps above all, these indicate a company's specific processes and ethical distinctiveness. The latter is important to an environmentally conscious and responsible market segment. These distinctions are also signs of social quality in the agri-food sector and enable companies to create, capture and share value. 


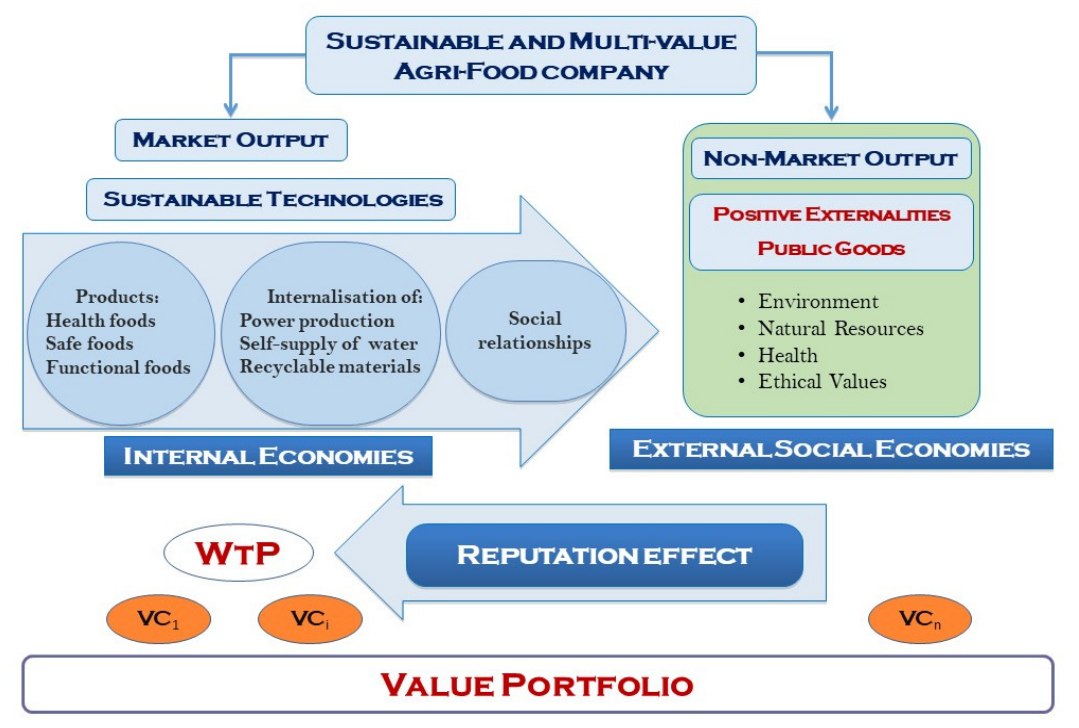

Figure 1. The sustainable and multi-value agri-food company. Source: Our elaboration.

In the new concept of competitiveness, sustainability and citizen-consumer protection become essential strategic levers to change economic challenges into opportunities for growth and development. From this perspective, the value portfolio-or socially responsible agri-food companies' market positioning-is the result of

- Its economic strength related to traditional competitive factors, such as costs, production and market differentiation. This component can be defined as a market value chain that produces benefits for the company;

- Its social strength related to the ability to meet citizen-consumers' expectations regarding the environment and society. This component can be defined as a social value chain or a producer of benefits for society. These benefits improve business performance and indirectly contribute to improving the market value chain by increasing consumers' WTP.

This model of a socially responsible agri-food company offers new development opportunities while increasing the creation of value. This also provides an ethical solution to the threats of market liberalisation in a normative asymmetry context. Further, it is an innovative perspective for developing territories and local communities, particularly in developed countries.

The agri-food company is socially responsible if its value portfolio introduces elements of social value that are clearly recognisable, have explicit connotations in the corporate development strategy and are oriented towards the creation of value in the medium- to long-term.

\subsection{The Life Cycle of Corporate Social Responsibility: A Methodological Approach}

Sustainable and multi-value agri-food companies' value portfolios are increasingly influenced by the size of intangible components-such as social value chains-that have become increasingly relevant to citizen-consumers. This component is subsequently affected by the company's orientation towards CSR. However, this orientation is recognised as a dynamic behaviour with different configurations in different companies and sectors due to its strict connection to the characteristics of the company's internal resources, stakeholders, and territory and to the space-time context in which it operates. The different CSR approaches are further accentuated in the agri-food sector, where they have only recently developed, and where the manufacturing sector may influence the company's choices of the specific CSR dimensions in which to invest.

The changes that occur within socially responsible companies differ based on (i) the historical context; (ii) the company's internal and external resources activated in its value-creation processes; 
and (iii) the manufacturing sector. However, these all rely on a sequence of different developmental stages. This study focuses on the idea that the sequence of CSR developmental stages can be explained through the life cycle model [50], as illustrated in the following Figure 2.

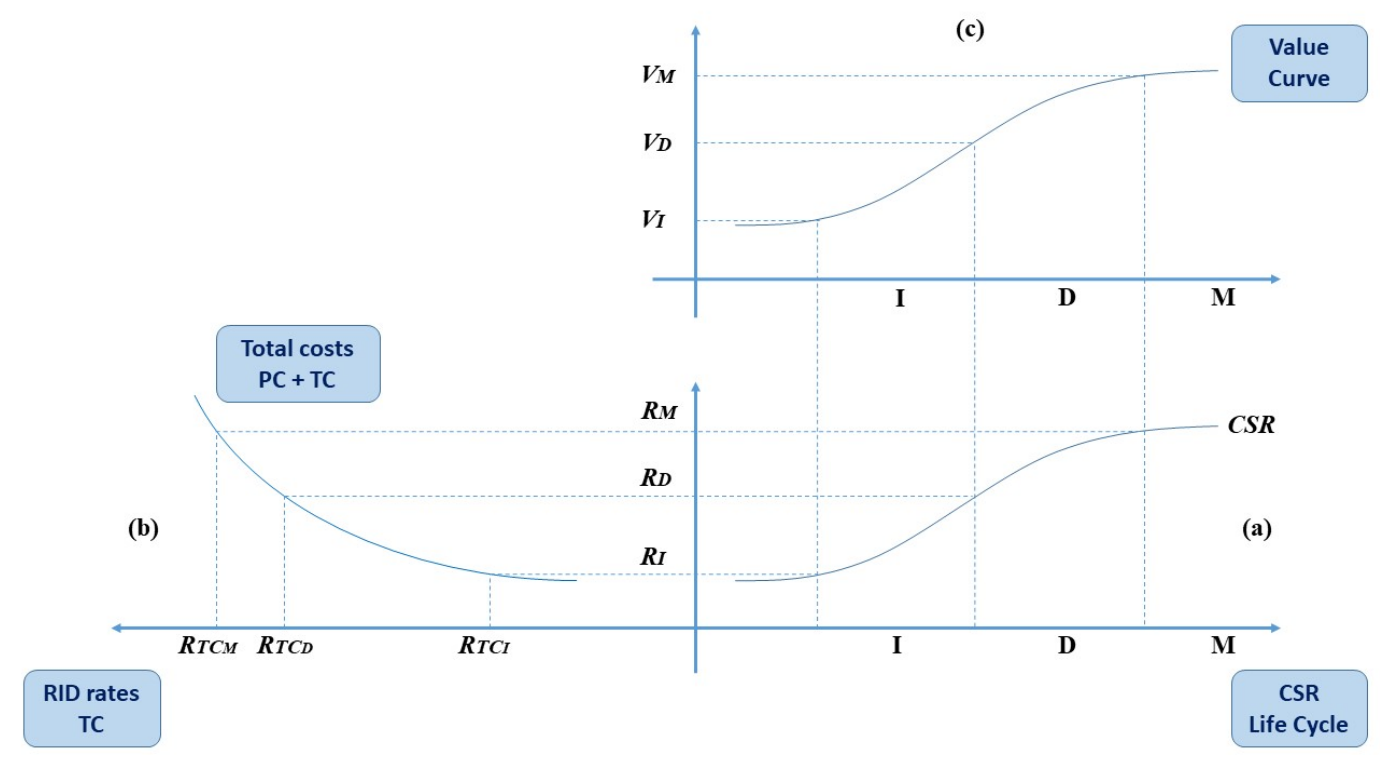

Figure 2. The corporate social responsibility (CSR) life cycle and economic performance in agri-food companies. Source: Our elaboration.

In other words, and as Figure 2a demonstrates, an agri-food company oriented towards social responsibility expresses this orientation in three stages: the initial (I), development (D) and maturity (M) stages. As the orientation towards social responsibility increases, the company's reputation (R) also increases. The latter leads to a decrease in company total costs (TC), as noted in Figure 2b, and particularly, a decrease in production (PC) — due to improved labour productivity resulting from an increase in workers' motivations and sharing the company mission-and transaction costs (TRC). This is due to increased reputation due to the company's increased orientation towards the production of common goods. The rate of reduction of total costs is shown on x-axis: As company internal and external reputation $(R)$ increases, the rate of reduction of total costs decreases.

This increased reputation also generates a "trust effect" among responsible citizen-consumers towards the company's goods and services. Consequently, these citizen-consumers are willing to recognise the premium pricing through a higher WTP. These two effects-decreased costs and premium pricing - create value for the company (business performance), as noted in Figure 2c.

Table 1 displays the results from investigating (i) the stage of the CSR life cycle in which the company is located and (ii) the CSR's effects on value creation in terms of reputation, decreased costs and evolved business performance.

In the initial stage of the CSR life cycle, the company begins to open up to a new corporate culture and vision and exceed its legal obligations. This stage also highlights the partial effects from some of the three factors that characterise the orientation towards social responsibility.

In the second purported "development" stage, the orientation towards CSR is such that most of the indicated elements are considered, while the company's socially responsible activities are recognised internally and externally to place it in this development phase.

Finally, in the maturity stage, the implemented CSR actions are perfectly integrated and consolidated in the business' management, and they are widely perceived both inside and outside the company. The company's behaviour in this stage is entirely based on its respect for the rules of ethics, and society fully recognises its CSR activities. 
Table 1. Matrix of CSR value creation.

\begin{tabular}{cccc}
\hline Value Creation & INITIAL & Life Cycle Stages & MEVELOPMENT \\
\hline Reputation & $\begin{array}{c}\text { Initial perceptions, whether } \\
\text { internal or external, of ethical } \\
\text { behaviour }\end{array}$ & $\begin{array}{c}\text { Widespread perceptions, } \\
\text { whether internal or external, of } \\
\text { ethical behaviour }\end{array}$ & $\begin{array}{c}\text { Recognition and consolidation, } \\
\text { whether internal or external, of } \\
\text { ethical behaviour }\end{array}$ \\
\hline Total Costs & $\begin{array}{c}\text { Slight decrease in total } \\
\text { company costs }\end{array}$ & $\begin{array}{c}\text { Significant decrease in total } \\
\text { company costs }\end{array}$ & $\begin{array}{c}\text { Consistent decrease in total } \\
\text { company costs }\end{array}$ \\
\hline and Value Creation & $\begin{array}{c}\text { Mild market perceptions of } \\
\text { ethical content in the } \\
\text { company's goods and services }\end{array}$ & $\begin{array}{c}\text { Significant market perceptions } \\
\text { of ethical content in the } \\
\text { company's goods and services }\end{array}$ & $\begin{array}{c}\text { Premium prices paid for the } \\
\text { company's goods and services, } \\
\text { as they are considered to be } \\
\text { highly ethical }\end{array}$ \\
\hline
\end{tabular}

Source: Our elaboration.

Therefore, the company's degree of orientation towards CSR and its location in the three stages of the life cycle depends on the intensity of integration of "ethical rules" within the decision-making processes: ethics are introduced in the initial stage, these become integrated into a large part of the company's choices in the developmental stage, and they become a consolidated reference for every entrepreneurial choice in the maturity stage.

However, moving from one stage in the CSR life cycle to another requires an analysis of available resources and of those that need to be acquired, and it is necessary for management to constantly evaluate the company's level of results. In fact, an erroneous or poor evaluation can cause the company to lose sight of useful actions to increase the level of current CSR activities, leading to a stagnation of this strategy and nullifying the investments already made. Therefore, it is essential to identify objective indicators that guarantee correct measurements of companies' CSR orientation and the life cycle stage achieved in the economic, environmental and social dimensions. An analysis of the current literature revealed a set of different criteria and indicators useful for this study's objectives. Indeed, most of these criteria have been defined by standards or studies considered in the empirical phase of this study $[6,13,51,52]$.

\subsection{Methodology and Study Design}

The present study reports the results of an initial analysis aimed at validating the proposed theoretical approach, and more specifically, to

(a) Determine the CSR orientation and life cycle phase of particular agri-food companies through specific indicators of environmental, social and economic sustainability;

(b) Investigate whether the company's CSR orientation improved its reputation and provided the citizen-consumer a greater propensity to purchase the company's products; and

(c) Verify our hypotheses to confirm whether and how the specific manufacturing sector can orient companies to implement actions related to one specific CSR dimension versus another.

An exploratory analysis was conducted of three case studies of agro-food companies: an olive oil mill, pasta factory and liquor enterprise. A case study approach was used for this phase because it allowed us comparatively analyse three companies operating in different sectors. Further, the case study methodology, as demonstrated in the literature [53], lends itself to the initial exploratory research of a new or rarely studied phenomenon or to the testing of a new theoretical model, as in our specific case.

These companies were selected given the importance of their CSR activities, and selection was not based on their territorial location. Specifically, the selected enterprises represent the main players of sustainable and socially responsible behaviour in the Italian market and in their respective sectors by combining innovation and tradition.

The surveys were conducted at the beginning of 2019, while the data refer to a three-year period spanning from 2016 to 2018. 
Each considered company's CSR life cycle was defined through a multi-step analysis:

First Step: Eight focus groups comprising company management and sectoral experts were organised. A questionnaire built through the use of specific indicators was finalised to measure the three dimensions of social responsibility (environmental, social and economic).

The indicators considered to determine the environmental dimension of CSR were

- The internalisation of energy production, such as production from renewable sources;

- A self-supply of water, such as reusing wastewater;

- Packaging made from recycled materials;

- $\quad$ Use of KTS technology;

- $\quad$ Use of KTT technology;

- Reduction of carbon dioxide $\left(\mathrm{CO}_{2}\right)$ emissions;

- Environmentally sustainable standards, such as suppliers that meet the company's standards; and

- Environmental certifications, such as investments for environmental purposes.

The indicators considered to investigate the social dimension of CSR were

- $\quad$ Employee training, such as the training hours delivered;

- The number of female employees;

- The number of foreign workers;

- $\quad$ Health care for employees;

- $\quad$ The adoption of flexible contracts;

- Flexible timetables;

- $\quad$ Part-time labour;

- $\quad$ Access to expectations;

- Information provided to consumers, such as costs for the company's initiatives;

- $\quad$ Corporate sponsorship of events, including costs for such initiatives; and

- Donations.

The indicators considered to assess the economics dimension of CSR were

- Healthy products;

- Safe products;

- Functional products;

- $\quad$ Products for minor categories;

- $\quad$ A local market presence; and

- $\quad$ Research and development (R\&D) investments.

Second Step: Each indicator was detected through a specific scale of percentage values for the initial, development and maturity stages in the CSR life cycle. After normalisation, these values were placed in ascending order on a common scale with extremes ranging from 0 to 9 and were divided based on the different stages of the CSR life cycle:

- $\quad 0$ to 3 for the initial stage;

- $\quad 3$ to 6 for the developmental stage; and

- 6 to 9 for the maturity stage.

Finally, the number of indicators for each considered company belonging to each of the three CSR life cycle stages was related to the total number of indicators to investigate the degree of CSR orientation in percentage terms.

Third Step: The companies' financial statements were examined to verify the company CSR initiatives' impacts on the creation of corporate value. Further, we investigated not only the "reputation 
effect", determined as a decrease in production costs, but also decreased transaction costs through 12 detailed, face-to-face interviews with the companies' management. (Transaction costs were considered as the sum of the costs incurred by the company for: (i) the research, evaluate and selection of customers and suppliers; (ii) the negotiation of contractual terms; (iii) to check and ensure that the contractual terms are respected and those eventually incurred for supported for arbitration in the event of disagreements over the contractual clauses) [54] The greater propensity to purchase company products was instead only indirectly examined through an analysis of company turnover.

\section{Case Studies}

All the investigated companies—an olive oil mill, pasta factory and liquor enterprise-are located in southern Italy; these are briefly described as follows:

Olive Oil Mill. The first company addressed in the study was an olive oil mill (Table 2). The company has recently become internationally relevant and has invested in sustainable innovation in its products and production processes. It has annual sales of approximately 72 million euros, gained by selling 100 million litres of olive oil. The company holds substantial foreign market shares, or roughly $35 \%$ of its annual sales, and it also has a plant in New York. As it internalises several stages of the production process-such as its packaging process—-the company employed 88 people in 2018, with a very low average age.

Table 2. Companies' descriptions.

\begin{tabular}{cccccc}
\hline Company & $\begin{array}{c}\text { Annual } \\
\text { Production }\end{array}$ & $\begin{array}{c}\text { SALES (in } \\
\text { Millions of Euros) }\end{array}$ & $\begin{array}{c}\text { EXPORTS (\% } \\
\text { of Sales) }\end{array}$ & $\begin{array}{c}\text { Number of } \\
\text { Plants }\end{array}$ & $\begin{array}{c}\text { Number of } \\
\text { Employees }\end{array}$ \\
\hline Olive oil mill & 100 million litres & 72 & 35 & 1 & 88 \\
\hline Pasta factory & 140 tonnes & 78 & 40 & 2 & 154 \\
\hline Liquor company & one million litres & 12 & 12 & 6 & 69 \\
\hline & Source: Our elaboration.
\end{tabular}

Pasta Factory. The second company considered was a pasta factory that combines innovation and tradition in the production process by adopting an ancient "slow processing"' transformation method (Table 2). The pasta factory produces approximately 140,000 tons of pasta per year, with sales of 78 million euros. It has two plants, one of which is located in northern Italy: the main plant has seven lines of production and 19 packaging lines and employs 154 people. Additionally, it exports approximately $40 \%$ of its sales, as the company sells pasta in 45 foreign countries, primarily in the United Kingdom, Germany, the United States and Japan.

Liquor Company. This company produces craft liquor with characteristics strongly linked to its territory of origin (Table 2). It produces one million litres annually, with sales of approximately 12 million euros and $12 \%$ of its sales coming from exports. It has several plants abroad-in Libya, France, Switzerland, Brazil and Argentina-and its liquor is sold in 50 different countries. Further, its Italian plant employs 69 employees.

As social responsibility is a voluntary initiative, its adoption is strictly linked to the production process or to the product to generate a different CSR life cycle in each considered company.

The olive oil mill's production process requires substantial quantities of water that generate significant amounts of wastewater [55,56]. Accordingly, the olive oil mill could be motivated to reuse wastewater to reduce production costs. Thus, the following set of scenarios was developed based on evidence from the literature:

Hypothesis 1. (H1) The olive oil mill reuses its wastewater. 
Moreover, the company produces olive oil that is rich in natural antioxidants $[57,58]$. Therefore, this industry may produce and promote its healthy olive oil through various communication strategies.

Hypothesis 2. (H2) The olive oil mill produces and promotes healthy products.

Citizen-consumers' preferences for healthy and safe food have increased over the last decade $[59,60]$. Simultaneously, scientists have largely demonstrated the negative effect of glyphosate, used in wheat cultivation, on human health [61-63]. In this scenario, the pasta factory could be oriented towards promoting safe products.

Hypothesis 3. (H3) The pasta factory is oriented towards producing safe, functional products.

Unlike the previous companies observed in this study, the liquor company creates a product with high cultural value that may be oriented towards enhancing communication campaigns to educate consumers regarding their alcohol consumption.

Hypothesis 4. (H4) The liquor company is oriented towards products with high cultural value and towards responsible consumer education initiatives.

\section{Results and Discussion}

\subsection{The Olive Oil Mill's CSR Life Cycle}

Our results indicate that the olive oil mill is still in an initial stage in the CSR life cycle. Indeed, $56 \%$ of the investigated indicators (five environmental, six social and three economic) are in an initial stage, while $20 \%$ of the overall indicators (three environmental and two social) are in a developmental stage. Finally, only $24 \%$ of the overall indicators (three social and three economic) are in a maturity stage (Figure 3).

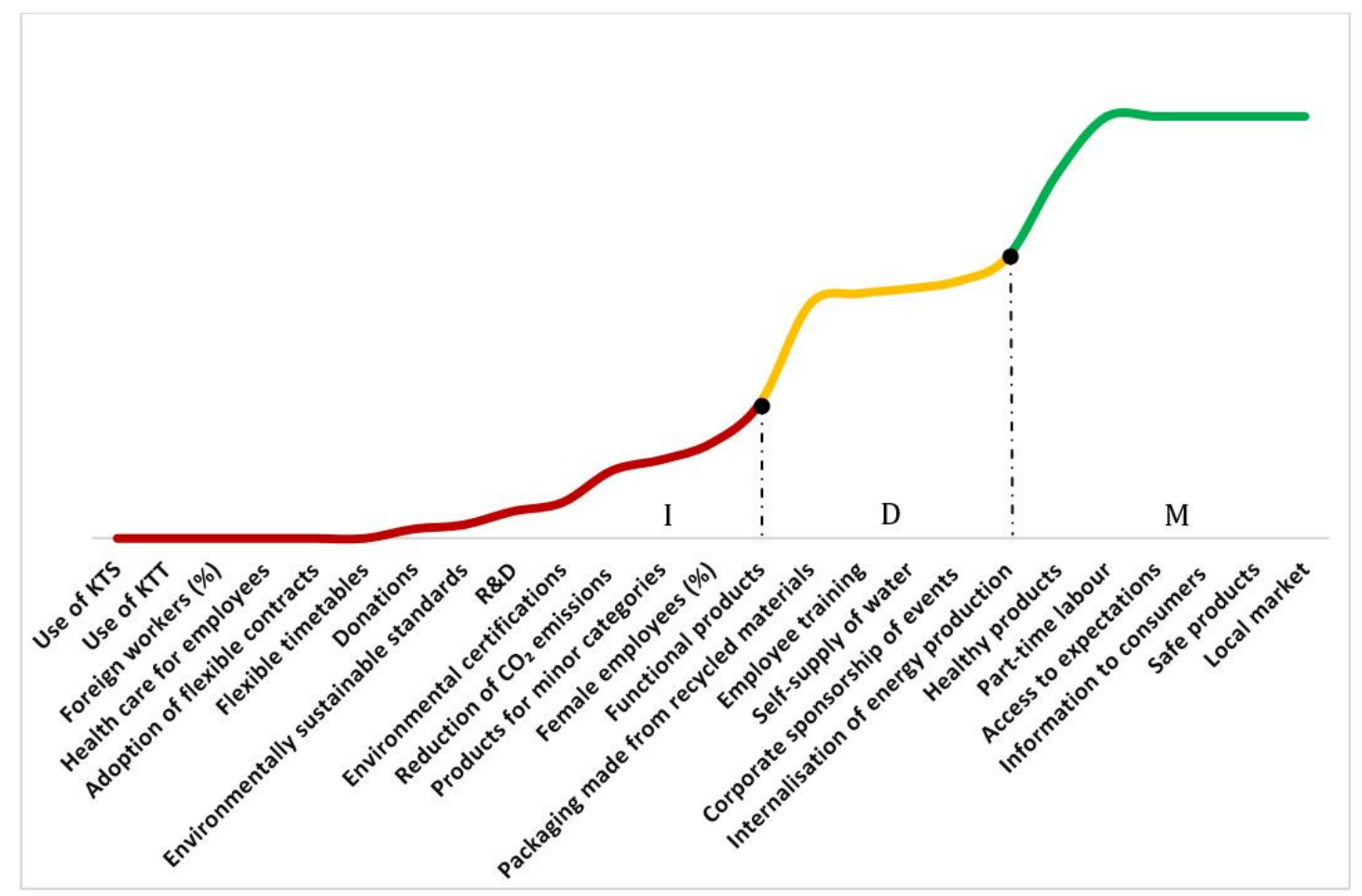

Figure 3. The olive oil mill's CSR life cycle. Source: Our elaboration. 
Specifically, the maturity stage of the CSR life cycle in the olive oil mill includes both "social" and "economic" indicators. Regarding the former, both "part-time labour" and the "access to expectations" are in the maturity stage. The latter also includes "information to consumers" or consumer education and environmental and ethical values. In other words, this denotes the aptitude to communicate ethical and environmental values to consumers. The training of employees and the company sponsorship of cultural, social and sporting events are both in a developmental stage. Regarding economic indicators, the company is more oriented towards selling healthy, safe products in local markets. As for the "environmental" dimension of CSR, the olive oil mill is in a developmental stage. Although the company has partially internalised the production of energy by recovering wastewater and using recycled raw materials for packaging, such practices still appear in an intermediate stage of the CSR life cycle. However, the results support our first hypothesis (H1).

The study findings also revealed that the olive oil mill is oriented towards the production of healthy products, as hypothesized in $\mathrm{H} 2$.

Face-to-face interviews with company management and an analysis of financial statements demonstrated that an increase in sales $(+2.6 \%)$ occurred following the adoption of socially responsible practices in the three-year period investigated, which was connected to an increase in demand for the company's products. The commitment to the social dimension of CSR, such as work-life balance, and the internalisation of energy production and self-supply of water by reusing wastewater have produced compelling results: in the three-year period considered, production costs substantially decreased $(-19 \%)$. The company's positive corporate reputation has also allowed it to improve its contractual relationships, with a consequent slight reduction in transaction costs $(-3 \%)$.

\subsection{The Pasta Factory's CSR Life Cycle}

The pasta factory is in an initial stage in its CSR life cycle, as with the olive oil mill. In this case, the initial stage includes three environmental, eight social and three economic indicators, which represent $52 \%$ of those considered. In contrast, $28 \%$ are in the developmental stage (three environmental, two social and two economic), while only $20 \%$ are in the maturity stage (two environmental, one social and two economic). Figure 4 illustrates this life cycle.

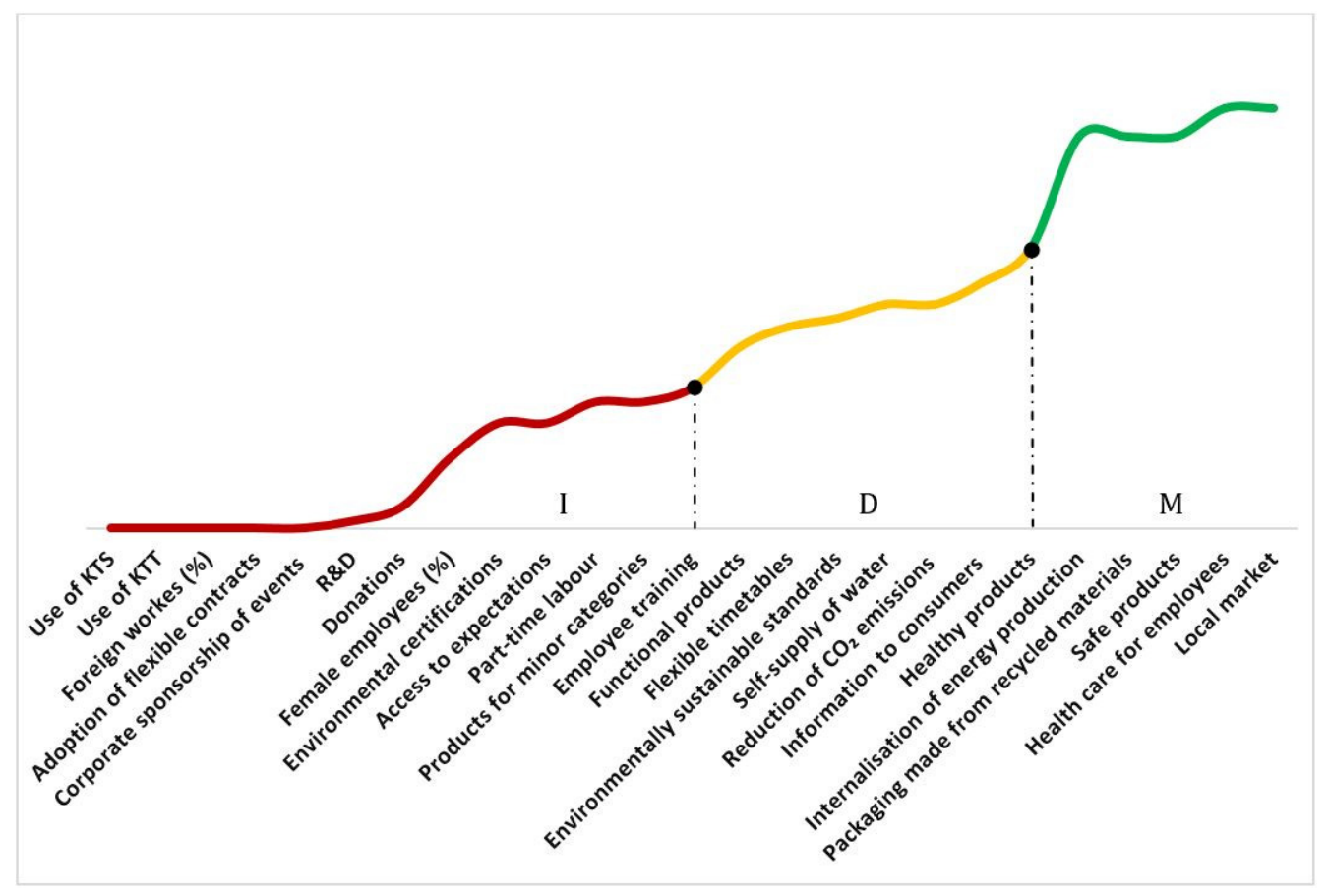

Figure 4. The pasta factory's CSR life cycle. Source: Our elaboration. 
In contrast to the olive oil mill, in which the environmental indicators still appear to be in a development stage, the pasta factory has adopted consolidated practices for internalising its energy production and in creating recyclable packaging.

Relative to its social and economic aspects, the company is in a maturity stage regarding its supplementary employee healthcare and the production of healthy, functional products, such as pasta enriched with natural antioxidants. Therefore, we note that although the pasta factory has only recently oriented towards CSR and is overall in an early stage of this life cycle, its actions would seem to be equally distributed among all environmental, social and economic CSR dimensions, as measured in this study.

Finally, Hypothesis (H3) is strongly supported, as the purported 'safe and functional products' indicator is in a maturity stage in the CSR life cycle.

Compared to the first company, the pasta factory's CSR orientation has more significantly impacted value creation. Comparing three-year financial statements spanning 2016 to 2018 and face-to-face interviews with company management reveals that although prices increased, demand increased to partially compensate for the company's CSR investments; this led to significant growth in company turnover $(+25 \%)$. Equally advantageous was the substantial decrease in production costs $(-23 \%)$. Compared to the olive oil mill company, such a decrease occurred due to the internalisation of energy production and to the creating of recyclable packaging. Finally, the pasta company also improved its governance with external stakeholders, as reflected by a decrease in transaction costs $(-5 \%)$.

\subsection{The Liquor Company's CSR Life Cycle}

This liquor company is clearly ranked in the initial stage of the CSR life cycle. Of its CSR indicators, $60 \%$ - or seven environmental, four social and four economic - are categorised in the initial stage, while $8 \%$ are in the developmental stage, representing only the social dimension of CSR. Finally, $32 \%$ of the considered indicators are in the maturity stage (one environmental, five social and two economic), as Figure 5 illustrates.

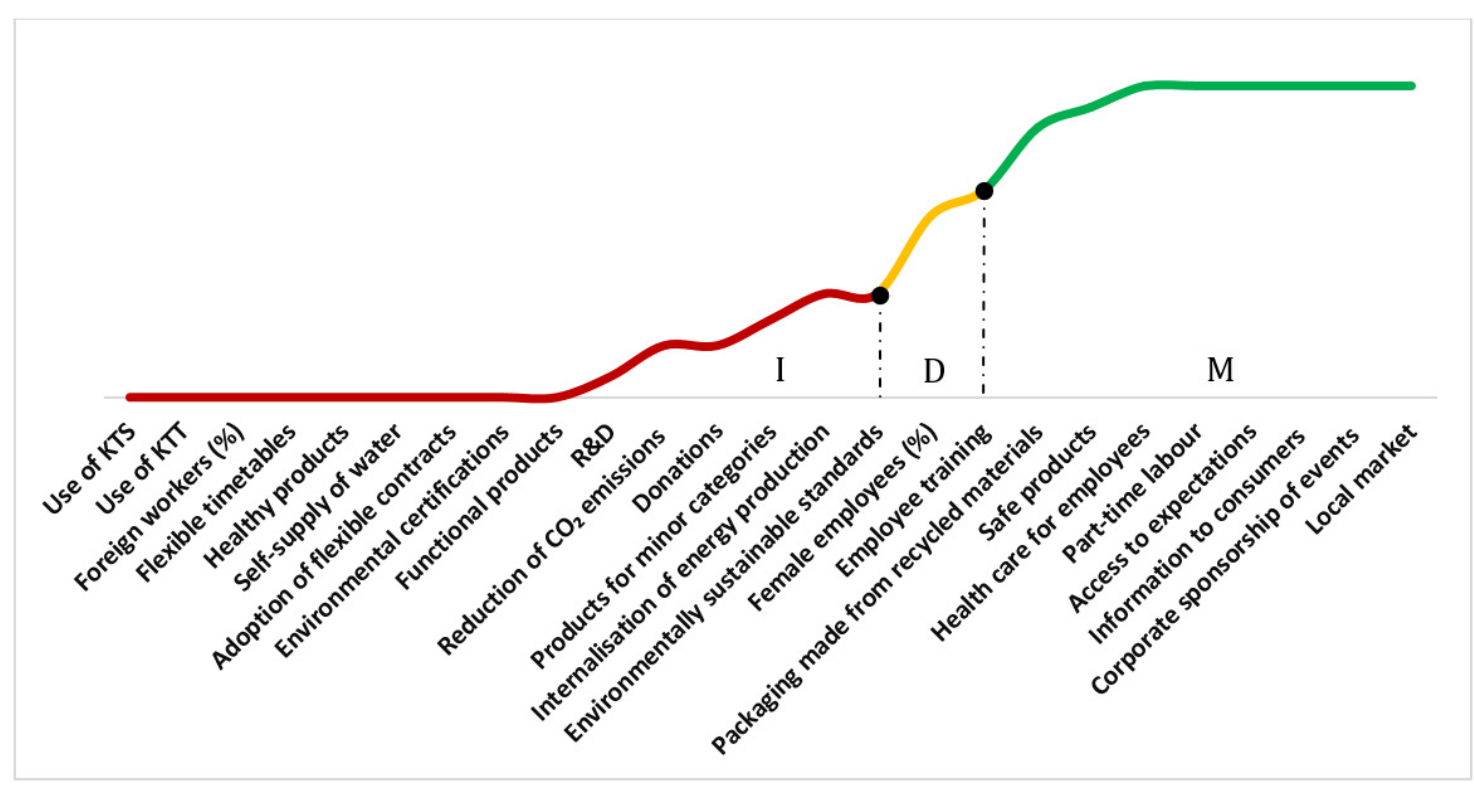

Figure 5. The liquor company's CSR life cycle. Source: Our elaboration.

The latter primarily comprises social indicators, such as supplementary health care for employees, part-time labour, access to the company's expectations, information made available to consumers and the sponsorship of events. In the same stage, two economic indicators are also found (safe products and local market) with one environmental indicator (recyclable packaging). Overall, the liquor company 
differs from the previous examined businesses as it presents many more indicators in the initial and maturity stages, reducing the number of indicators in the development stage.

Our results reveal that the liquor company appears to be more traditionally oriented compared with the other two cases. Specifically, it aims to produce liquor with high cultural value and connected to a literary prize, as hypothesized in H4. The company has consistently invested more in the social dimension of CSR, and particularly in cultural initiatives and information campaigns to promote responsible alcohol consumption (Hypothesis $\mathrm{H} 5$ ).

Moreover, the company's percentage of female employees and its employee training are only moderately developed; however, the company's human capital is critical for the liquor company, as the knowledge of traditional techniques is crucial for making a craft product. This company has adopted a code of conduct for labour recruitment that provides generational turnover within the same family to guarantee job opportunities for young people and convey the knowledge of the craft liquor from father to son.

The company is ranked in the initial stage of the CSR life cycle relative to its environmental dimension, as it has only recently focused on sustainable packaging practices in the last five years. Regarding the company's economic dimension, it has devoted considerable attention towards selling safe products in the local market. As the liquor company is primarily oriented towards social sustainability initiatives, which are still in an intermediate development phase, the effects on corporate value performance are not yet evident; the company indicated no changes in terms of turnover or in its production and transaction costs.

\subsection{A Comparative Analysis of the Three Case Studies}

To summarise the life cycle phases regarding each indicator within the three investigated companies, it is possible to observe how some of them exist in the same stage, although operating in different sectors. As illustrated in Table 3, it is possible to observe both a "local market presence" and the production of "safe products", which represents a consolidation of (economic) indicators in business strategies. The modern citizen-consumer considers these aspects as fundamental, as his or her purchase decisions will involve increasing attention towards products' origins and the health and safety attributes of which he is willing to recognise price premiums [64,65].

Investment in product and process innovations is still at an early stage in all the companies observed. This is because research and development investments, in most cases, are linked to research projects financed not from a company's own capital, but from EU funds. However, the adoption of innovation in the European agri-food sector is often generally linked to the external financing in which the company participates [66-68]. The initial phase also includes indicators related to the use of sustainable technologies (whether KTS- or KTT-type) and environmental certifications.

In terms of the CSR social dimension, most of the considered indicators occur in the development and maturity phases in all three company cases. In contrast, flexible work contracts and the percentage of foreign workers can be observed in the initial life cycle phase in all three investigated companies. The absence of flexible contracts found in these companies is primarily due to a low percentage of women employed, except in the liquor company, as well as the type of production. Few foreign workers are employed due to the companies' local networks (enterprise/territory) established with their employees' families, which has ensured a sort of generational change among entire families of employees in the company. 
Table 3. Summary of the life cycle stages of each indicator for each considered company.

\begin{tabular}{|c|c|c|c|}
\hline & $\begin{array}{l}\text { OLIVE OIL } \\
\text { MILL }\end{array}$ & $\begin{array}{c}\text { PASTA } \\
\text { FACTORY }\end{array}$ & $\begin{array}{l}\text { LIQUOR } \\
\text { COMPANY }\end{array}$ \\
\hline \multicolumn{4}{|c|}{ Environmental Indicators } \\
\hline Internalisation of energy production & $\mathrm{D}$ & $\mathrm{M}$ & $\mathrm{I}$ \\
\hline Self-supply of water & $\mathrm{D}$ & $\mathrm{D}$ & I \\
\hline Packaging made from recycled materials & $\mathrm{D}$ & M & $\mathrm{M}$ \\
\hline Use of sustainable technologies (KTS) & I & I & I \\
\hline Use of sustainable technologies (KTT) & I & I & I \\
\hline Reduction of $\mathrm{CO}_{2}$ emissions & I & $\mathrm{D}$ & I \\
\hline $\begin{array}{l}\text { Adoption of environmentally sustainable } \\
\text { standards }\end{array}$ & $\mathrm{I}$ & $\mathrm{D}$ & I \\
\hline Environmental certifications & I & I & I \\
\hline \multicolumn{4}{|c|}{ Social Indicators } \\
\hline Employee training & $\mathrm{D}$ & I & $\mathrm{D}$ \\
\hline Female employees (\%) & $\mathrm{I}$ & $\mathrm{I}$ & $\mathrm{D}$ \\
\hline Foreign workers (\%) & I & I & I \\
\hline Supplementary health care for employees & I & M & M \\
\hline Adoption of flexible contracts & I & I & I \\
\hline Flexible timetables & I & $\mathrm{D}$ & I \\
\hline Part-time labour & $\mathrm{M}$ & $\mathrm{I}$ & $\mathrm{M}$ \\
\hline Access to expectations & $\mathrm{M}$ & $\mathrm{I}$ & M \\
\hline $\begin{array}{c}\text { Information to consumers } \\
\text { (consumer education and environmental and } \\
\text { ethical values) }\end{array}$ & M & $\mathrm{D}$ & M \\
\hline $\begin{array}{c}\text { Corporate sponsorship of events (cultural, } \\
\text { social or sports-related) }\end{array}$ & $\mathrm{D}$ & I & M \\
\hline Donations & I & I & I \\
\hline \multicolumn{4}{|c|}{ Economic Indicators } \\
\hline Healthy products & $\mathrm{M}$ & $\mathrm{D}$ & I \\
\hline Safe products & M & M & M \\
\hline Functional products & $\mathrm{D}$ & $\mathrm{D}$ & I \\
\hline Products for minor categories & I & I & I \\
\hline Local market & $\mathrm{M}$ & M & M \\
\hline Product and/or process innovations (R\&D) & I & I & I \\
\hline
\end{tabular}

\section{Conclusions and Limitations}

The CSR life cycle model, as addressed in this study, enabled us to investigate the transformation process in place in agri-food companies. As observed, the latter has progressed towards socially responsible business models to tackle the environmental and citizen-consumer concerns, as the citizen-consumer is the primary driver of business changes. Indeed, its purchasing behaviour leads stakeholders to adopt sustainable, socially oriented production models in which the natural and environmental resources used become a lever for competitive advantage. Consequently, competitiveness changes to address sustainability and citizen-consumer issues. 
Therefore, the changes in competitiveness dynamics, as observed in our introductory remarks, have led companies to rethink their business model through value-creation models that aim to meet society's current needs. Specifically, and as this study demonstrates, companies have turned towards business models based on social and environmental protections, in which CSR is both central and a lever for competitive advantage.

The study's findings also reveal that CSR initiatives may affect business processes, such as the entire production process and/or the product or, specifically, as connected to some of the product's characteristics. Regarding the latter, the investigated case studies reveal that the production sector in which the company operates strongly influences the orientation towards one or more CSR dimensions. To this extent, this study indicates that by internalising the production input, companies such as the oil mill and pasta factory have generated both internal (i.e., reducing production and transaction costs) and social external economies (i.e., generating positive externalities linked to less environmental impact) that positively affect the creation of company value. These companies have significantly increased turnover, primarily due to their higher willingness to pay for the citizen-consumer as a consequence of stronger company reputations.

In summary, the life cycle model proposed in this analysis is an original and useful tool for a (self) evaluation of CSR performance in three dimensions: economic, social and environmental. Further, it enables companies' management to assess the results achieved and plan potential improvement initiatives.

Clearly, the study has some limitations related to the use of the case study methodology that do not allow us to generalise the results. Given this, future analyses could be conducted through empirical studies on a significant sample of companies operating in different supply chains and territories to validate the relationship between social responsibility strategies and implemented value-creation models.

\section{Policy Implications}

This study's findings provide implications for both decision makers and practitioners, as it contributes to the debate regarding the role of sectoral policies supporting the development of CSR practices in companies. It also suggests useful insights to define guidelines for actors in the agri-food system to implement socially responsible business models.

However, this study's hypothesis also poses new research questions aimed at assessing CSR actions' effectiveness in stakeholders' engagement and the sharing of value. For instance, the need exists to investigate entrepreneurship models in different governance structures and in managing sharing value in socially responsible agri-food chains.

Author Contributions: Introduction, conclusions and limitations: G.M.; corporate social responsibility and value creation models: conceptual framework - the sustainable and multi-value agri-food company, the life cycle of corporate social responsibility: a methodological approach, and methodology and study design: C.N.; case studies, results and discussion, policy implications: M.S. All authors have read and approved the final manuscript.

Funding: This research received no external funding.

Acknowledgments: We thank the management of the companies interviewed for their availability and friendliness. Moreover, we also want to thank the referees for their helpful suggestions.

Conflicts of Interest: The authors declare no conflicts of interest.

\section{References}

1. Hartmann, M. Corporate social responsibility in the food sector. Eur. Rev. Agric. Econ. 2011, 38, $297-324$. [CrossRef]

2. Luhmann, H.; Theuvsen, L. Corporate social responsibility in agribusiness: Literature review and future research directions. J. Agric. Environ. Ethic 2016, 29, 673-696. [CrossRef]

3. Bowen, H.R. Social Responsibilities of the Businessman; Harper and Row: New York, NY, USA, 1953. 
4. Öberseder, M.; Schlegelmilch, B.B.; Gruber, V. “Why don't consumers care about CSR?": A qualitative study exploring the role of CSR in consumption decisions. J. Bus. Ethic 2011, 104, 449-460. [CrossRef]

5. Costanigro, M.; Deselnicu, O.; McFadden, D.T. Product differentiation via corporate social responsibility: Consumer priorities and the mediating role of food labels. Agric. Hum. Value 2016, 33, 597-609. [CrossRef]

6. Commission of the European Communities. Green paper: Promoting a European Framework for Corporate Social Responsibility. 2001. Available online: https://ec.europa.eu/commission/presscorner/detail/en/DOC_ 01_9 (accessed on 5 December 2019).

7. European Commission. A renewed EU strategy 2011-14 for corporate social responsibility. Communication from the Commission to the European Parliament, the Council, the European Economic and Social Committee and the Committee of the Regions. 2011. Available online: https://eur-lex.europa.eu/legal-content/EN/ALL/ ?uri=COM:2015:614:FIN (accessed on 5 December 2019).

8. Hiss, S.B. Warum Übernehmen Unternehmen Gesellschaftliche Verantwortung? Ein Soziologischer Erklärungsversuch; Campus Verlag GmbH: Frankfurt, Germany, 2006.

9. Heyder, M.; Theuvsen, L. Legitimating Business Activities Using Corporate Social Responsibility: Is There a Need for CSR in Agribusiness? Available online: https://www.semanticscholar.org/paper/LegitimatingBusiness-Activities-Using-Corporate-Is-Heyder-Theuvsen/4b5c6a618fd43ccba28d0e0f6d7e43b43dffdd0e (accessed on 5 December 2019).

10. Assiouras, I.; Ozgen, O.; Skourtis, G. The impact of corporate social responsibility in food industry in product-harm crises. Br. Food J. 2013, 115, 108-123. [CrossRef]

11. Marotta, G.; Nazzaro, C.; Stanco, M. How the social responsibility creates value: Models of innovation in Italian pasta industry. Int. J. Glob. Small Bus. 2017, 9, 144-167. [CrossRef]

12. Elkington, J. Partnerships from cannibals with forks: The triple bottom line of 21st-century business. Environ. Qual. Manag. 1998, 8, 37-51. [CrossRef]

13. Verhees, F.; Kuipers, A.; Meulenberg, M. Marketing potential of corporate social responsibility in supply chains. J. Chain Netw. Sci. 2008, 8, 143-152. [CrossRef]

14. Marotta, G.; Nazzaro, C. Responsabilità Sociale e Creazione di Valore Nell'impresa Agroalimentare: Nuove Frontiere di Ricerca; Economia Agro-Alimentare: Milano, Italy, 2012.

15. Rusconi, G.; Dorigatti, M. La Responsabilità Sociale D'impresa; Franco Angeli: Milano, Italy, 2004.

16. Hinna, L. "Introduzione” alla tavola rotonda "L'approccio alla responsabilità sociale: Gli strumenti per le imprese". In La Responsabilità Sociale D'impresa: Un'opportunità per il Sistema Agroalimentare; INEA: Roma, Italy, 2010.

17. Briamonte, L. La responsabilità sociale nel sistema agroalimentare: Il percorso INEA. In La Responsabilità Sociale D'impresa: Un'opportunità per il Sistema Agroalimentare; INEA: Roma, Italy, 2010.

18. Schröder, M.J.; McEachern, M.G. Fast foods and ethical consumer value: A focus on McDonald's and KFC. Br. Food J. 2005, 107, 212-224. [CrossRef]

19. Heinen, S.; Hartmann, M. Corporate social responsibility in the German pork industry: Relevance and determinants. Proc. Food Syst. Dyn. 2013, 25-46. [CrossRef]

20. Rana, P.; Platts, J.; Gregory, M. Exploration of corporate social responsibility (CSR) in multinational companies within the food industry. In Queen's Discussion Paper Series on Corporate Responsibility Research; Queen's University Management School: Belfast, UK, 2009.

21. Heyder, M.; Theuvsen, L. Determinants and effects of corporate social responsibility in German agribusiness: A PLS model. Agribusiness 2012, 28, 400-420. [CrossRef]

22. Rejc, A.; Slapnicar, S. Determinants of performance measurement system design and corporate financial performance. Stud. Manag. Financ. Account. 2004, 14, 47-73.

23. Elford, A.C.; Daub, C.H. Solutions for SMEs Challenged by CSR: A Multiple Cases Approach in the Food Industry within the DACH-Region. Sustainability 2019, 11, 4758. [CrossRef]

24. Fiandrino, S.; Busso, D.; Vrontis, D. Sustainable responsible conduct beyond the boundaries of compliance: Lessons from Italian listed food and beverage companies. Br. Food J. 2019, 121, 1035-1049. [CrossRef]

25. Amaeshi, K.M.; Osuji, O.K.; Nnodim, P. Corporate social responsibility in supply chains of global brands: A boundaryless responsibility? Clarifications, exceptions and implications. J. Bus. Ethic 2008, 81, $223-234$. [CrossRef]

26. Ciliberti, F.; Pontrandolfo, P.; Scozzi, B. Investigating corporate social responsibility in supply chains: A SME perspective. J. Clean. Prod. 2008, 16, 1579-1588. [CrossRef] 
27. Manning, L. Corporate and consumer social responsibility in the food supply chain. Br. Food J. 2013, 115, 9-29. [CrossRef]

28. Kissinger, G. Corporate Social Responsibility and Supply Agreements in the Private Sector: Decreasing Land and Climate Pressures; CCAFS Working Paper 14; CCAFS: Copenhagen, Denmark, 2012.

29. Giacomarra, M.; Crescimanno, M.; Sakka, G.; Galati, A. Stakeholder engagement toward value co-creation in the F\&B packaging industry. EuroMed J. Bus. 2019. [CrossRef]

30. Pucci, T.; Casprini, E.; Galati, A.; Zanni, L. The virtuous cycle of stakeholder engagement in developing a sustainability culture: Salcheto winery. J. Bus. Res. 2018. [CrossRef]

31. Wiese, A.; Toporowski, W. CSR failures in food supply chains-An agency perspective. Br. Food J. 2013, 115, 92-107. [CrossRef]

32. Oppewal, H.; Alexander, A.; Sullivan, P. Consumer perceptions of corporate social responsibility in town shopping centres and their influence on shopping evaluations. J. Retail. Consum. Serv. 2006, 13, 261-274. [CrossRef]

33. Pirsch, J.; Gupta, S.; Grau, S.L. A framework for understanding corporate social responsibility programs as a continuum: An exploratory study. J. Bus. Ethic 2007, 70, 125-140. [CrossRef]

34. Gupta, S.; Pirsch, J. The influence of a retailer's corporate social responsibility program on re-conceptualizing store image. J. Retail. Consum. Serv. 2008, 15, 516-526. [CrossRef]

35. Hartmann, M.; Heinen, S.; Melis, S.; Simons, J. Consumers' awareness of CSR in the German pork industry. Br. Food J. 2013, 115, 124-141. [CrossRef]

36. Pino, G.; Amatulli, C.; De Angelis, M.; Peluso, A.M. The influence of corporate social responsibility on consumers' attitudes and intentions toward genetically modified foods: Evidence from Italy. J. Clean. Prod. 2016, 112, 2861-2869. [CrossRef]

37. Nazzaro, C.; Lerro, M.; Stanco, M.; Marotta, G. Do consumers like food product innovation? An analysis of willingness to pay for innovative food attributes. Br. Food J. 2019, 121, 1413-1427. [CrossRef]

38. Lerro, M.; Caracciolo, F.; Vecchio, R.; Cembalo, L. Consumer's Side of Corporate Social Responsibility: A Nonhypothetical Study. J. Consum. Aff. 2018, 52, 689-710. [CrossRef]

39. Lerro, M.; Raimondo, M.; Stanco, M.; Nazzaro, C.; Marotta, G. Cause Related Marketing among Millennial Consumers: The Role of Trust and Loyalty in the Food Industry. Sustainability 2019, 11, 535. [CrossRef]

40. Aktar, I. Disclosure strategies regarding ethically questionable business practices. Br. Food J. 2013, 115, 162-193. [CrossRef]

41. Lerro, M.; Vecchio, R.; Nazzaro, C.; Pomarici, E. The growing (good) bubbles: Insights into US consumers of sparkling wine. Br. Food J. 2019, in press.

42. Turban, D.B.; Greening, D.W. Corporate social performance and organizational attractiveness to prospective employees. Acad. Manag. J. 1997, 40, 658-672.

43. Valentine, S.; Godkin, L.; Fleischman, G.M.; Kidwell, R. Corporate ethical values, group creativity, job satisfaction and turnover intention: The impact of work context on work response. J. Bus. Ethics 2011, 98, 353-372. [CrossRef]

44. Barakat, S.R.; Isabella, G.; Boaventura, J.M.G.; Mazzon, J.A. The influence of corporate social responsibility on employee satisfaction. Manag. Decisio 2016, 54, 2325-2339. [CrossRef]

45. Briones Peñalver, A.J.; Bernal Conesa, J.A.; de Nieves Nieto, C. Analysis of corporate social responsibility in Spanish agribusiness and its influence on innovation and performance. Corp. Soc. Responsib. Environ. Manag. 2018, 25, 182-193. [CrossRef]

46. Forsman-Hugg, S.; Katajajuuri, J.M.; Pesonen, I.; Paananen, J.; Makela, J.; Timonen, P. Building the Content of CSR in the Food Chain with a Stakeholder Dialogue. Available online: https://pdfs.semanticscholar.org/ 7d96/f4c2810fc1068efa76cc99a4e1b6f249b716.pdf (accessed on 5 December 2019).

47. Kong, D. Does corporate social responsibility matter in the food industry? Evidence from a nature experiment in China. Food Policy 2012, 37, 323-334. [CrossRef]

48. Raynaud, E.; Valceschini, E. Creation and Capture of Value in Sectors of the Agri-Food Chains: Strategies and Governance. Available online: https://www.researchgate.net/publication/282601735_Creation_and_capture_ of_value_in_sectors_of_the_agri-food_chains_strategies_and_governance (accessed on 5 December 2019).

49. Marotta, G.; Nazzaro, C. Verso un nuovo paradigma per la creazione di valore nell'impresa agricola multifunzionale. Il caso della filiera zootecnica. Econ. Agro Aliment. 2011. [CrossRef] 
50. Gardner, D.M. (Ed.) The life cycle model, was traditionally applied, in the managerial literature, to describe and analyse the stages that characterize the evolution-over time-of a new or reformulated product. The product life cycle: A critical look at the literature. In BEBR Faculty Working Paper; No. 1336; College of Commerce and Business Administration, University of Illinois at Urbana-Champaign: Champaign County, IL, USA, 1987.

51. Hoefkens, C.; Veettil, P.C.; Van Huylenbroeck, G.; Van Camp, J.; Verbeke, W. What nutrition label to use in a catering environment? A discrete choice experiment. Food Policy 2012, 37, 741-750. [CrossRef]

52. CCPB. Documento Tecnico. Valutazione Degli Impatti Ambientali e Dell'energia Rinnovabile Utilizzata Nel Ciclo di vita dei Prodotti Agroalimentari. Available online: http://www.agricolturanews.it/files/2012/05/ Documento-Tecnicno-CCPB.pdf (accessed on 10 January 2017).

53. Yin, R.K. Case Study Research, 4th ed.; SAGE: Beverly Hills, CA, USA, 2009.

54. Coase, R. The Problem of Social Cost. J. Law Econ. 2007, 56, 1-13.

55. Dermeche, S.; Nadour, M.; Larroche, C.; Moulti-Mati, F.; Michaud, P. Olive mill wastes: Biochemical characterizations and valorization strategies. Process Biochem. 2013, 48, 1532-1552. [CrossRef]

56. Paraskeva, P.; Diamadopoulos, E. Technologies for olive mill wastewater (OMW) treatment: A review. J. Chem. Technol. Biotechnol. Int. Res. Process Environ. Clean Technol. 2006, 81, 1475-1485.

57. Rigacci, S.; Stefani, M. Nutraceutical properties of olive oil polyphenols. An itinerary from cultured cells through animal models to humans. Int. J. Mol. Sci. 2016, 17, 843. [CrossRef]

58. Serreli, G.; Deiana, M. Biological Relevance of Extra Virgin Olive Oil Polyphenols Metabolites. Antioxidant 2018, 7, 170. [CrossRef]

59. Grunert, K.G.; Sonntag, W.I.; Glanz-Chanos, V.; Forum, S. Consumer interest in environmental impact, safety, health and animal welfare aspects of modern pig production: Results of a cross-national choice experiment. Meat Sci. 2018, 137, 123-129. [CrossRef]

60. Pappalardo, G.; Chinnici, G.; Pecorino, B. Assessing the economic feasibility of high heat treatment, using evidence obtained from pasta factories in Sicily (Italy). J. Clean. Prod. 2017, 142, 2435-2445. [CrossRef]

61. Van Bruggen, A.H.C.; He, M.M.; Shin, K.; Mai, V.; Jeong, K.C.; Finckh, M.R.; Morris, J.G., Jr. Environmental and health effects of the herbicide glyphosate. Sci. Total Environ. 2018, 616, 255-268. [CrossRef] [PubMed]

62. Bai, S.H.; Ogbourne, S.M. Glyphosate: Environmental contamination, toxicity and potential risks to human health via food contamination. Environ. Sci. Pollut. Res. 2016, 23, 18988-19001. [CrossRef] [PubMed]

63. Hoffmann, A.R.; Proctor, L.M.; Surette, M.G.; Suchodolski, J.S. The microbiome: The trillions of microorganisms that maintain health and cause disease in humans and companion animals. Vet. Pathol. 2016, 53, 10-21. [CrossRef]

64. Jo, J.; Lusk, J.L.; Muller, L.; Ruffieux, B. Value of parsimonious nutritional information in a framed field experiment. Food Policy 2016, 63, 124-133. [CrossRef]

65. Feldmann, C.; Hamm, U. Consumers' perceptions and preferences for local food: A review. Food Qual. Prefer. 2015, 40, 152-164. [CrossRef]

66. Détang-Dessendre, C.; Geerling-Eiff, F.A.; Guyomard, H.; Poppe, K.J. EU Agriculture and Innvation: What Role for the CAP? Wageningen University \& Research: Wageningen, Holland, 2018.

67. Bonfiglio, A.; Camaioni, B.; Coderoni, S.; Esposti, R.; Pagliacci, F.; Sotte, F. The Rural Development Policy and the support to innovation and education. Which role for rural and remote EU regions? In Proceedings of the 4th AIEAA Conference "Innovation, productivity and growth: Towards sustainable agri-food production", Ancona, Italy, 11-12 June 2015.

68. Avermaete, T.; Viaene, J.; Morgan, E.J.; Pitts, E.; Crawford, N.; Mahon, D. Determinants of product and process innovation in small food manufacturing firms. Trends Food Sci. Technol. 2004, 15, 474-483. [CrossRef]

(C) 2020 by the authors. Licensee MDPI, Basel, Switzerland. This article is an open access article distributed under the terms and conditions of the Creative Commons Attribution (CC BY) license (http://creativecommons.org/licenses/by/4.0/). 